\title{
1. Corporate governance and entrepreneurship: current states and future directions
}

\author{
Jonas Gabrielsson
}

\section{INTRODUCTION}

Scholarly research positioned in the intersection of corporate governance and entrepreneurship has grown considerably in scale and scope during the past two decades. While mainstream research on corporate governance has been much concerned with large, publicly listed corporations (Daily et al., 2003; Gabrielsson and Huse, 2004) this particular research stream has addressed issues and problems specifically related to corporate governance in entrepreneurial settings (Huse, 2000; Daily et al., 2002; Gabrielsson and Huse, 2010). The research includes a range of various entrepreneurial settings, such as start-ups (e.g., Grundei and Talaulicar, 2002; Ingley and McCaffrey, 2007), venture capital (VC)financed ventures (e.g., Rosenstein, 1988; Gabrielsson and Huse, 2004) and fast-growing firms (e.g., Nelson and Levesque, 2007; Wirtz, 2011), as well as organized efforts to support entrepreneurship and innovation in established corporations (e.g., Zahra, 1996; Zahra et al., 2000). This volume seeks to explore and expand on the rich body of knowledge that has emerged and developed in this direction.

Both corporate governance and entrepreneurship are multidisciplinary fields of research where scholars are interested in providing actionable knowledge relevant for the phenomena studied. Research in entrepreneurship seeks to understand the actors, actions, resources, environmental influences and outcomes associated with the emergence of opportunities to create future goods and services and/or the emergence of new economic activities (Landström, 2010). While the most common example may include the process of starting a new business (Gartner, 1985; Davidsson, 1995) it is widely acknowledged that entrepreneurship can be found in multiple organizational contexts, including small growing firms (Davidsson, 1991; Delmar et al., 2003) and mature corporations (Covin and Miles, 1999; Garvin and Levesque, 2006) as well as public and nonprofit organizations (Morris and Jones, 1999; Kearney et al., 2008).

Entrepreneurship that emerges and develops into organized forms 
of economic activity generates challenges with respect to the coordination and control of resources (Markman et al., 2001; Daily et al., 2002). Research in corporate governance addresses these challenges by seeking to understand how corporate power is directed in socially beneficial ways, both within and across economies (Judge et al., 2012, p. 88). While definitions of corporate governance vary, they typically include the set of systems, principles and processes by which an enterprise is directed and controlled (Thomsen and Conyon, 2012; Tihanyi et al., 2014). This encompasses a range of various institutional arrangements within firms, such as structures and forms of ownership (e.g., Pedersen and Thomsen, 2003), the board of directors (e.g., Forbes and Milliken, 1999), compensation systems for managers (e.g., Conyon, 2006), financial reporting systems (e.g., Beusenlinck and Manigart, 2007) and auditing (e.g., Cohen et al., 2010). However, it also includes a wider set of institutional arrangements surrounding the firm, such as state legislation and regulations (e.g., La Porta et al., 2000), corporate networks and managerial labor markets (e.g., Sinani et al., 2008) and competition on product markets (e.g., Giroud and Mueller, 2011), as well as pressure from the media (e.g., Bednar, 2012). In this respect, the study of corporate governance can be described as a relatively broad area of research where multiple social science disciplines collectively contribute to the scholarly understanding of the antecedents and consequences of the various institutional arrangements that conditions corporate governance in different organizational and geographical contexts.

The interest in developing scholarly knowledge in the intersection of corporate governance and entrepreneurship can in many ways be traced back to Professor Myles Mace at Harvard University, a pioneer in the study of both entrepreneurship and corporate governance. In his early observations of boards in small corporations, Mace (1948) concluded that they were seldom little more than fictional legal organs 'which included merely subservient and docile appointees of the ownermanager' (p. 87). This was also a dominant message in his book (Mace, 1971) and Harvard Business Review article (Mace, 1972). In the 1980s, when research on entrepreneurship and small businesses was starting to ascend as a distinct academic field of research (Landström, 2010), a number of studies continued in this direction by exploring corporate governance practices in smaller corporations (e.g., Castaldi and Wortmann, 1984; Ford, 1988; Nash, 1988; Huse, 1990). Overall, this early stream of research typically emphasized the board of directors as a potential resource in smaller firms that could serve as a valuable source of advice and counsel, offering discipline value and also acting in situations of crisis. 
The body of scholarly knowledge positioned in the intersection of corporate governance and entrepreneurship has expanded considerably since the first pioneering contributions by Mace $(1948,1971)$ and others. The general interest in exploring and examining the corporate governance practices of small corporations has continued (e.g., Bennett and Robson, 2004; Durst and Henschel, 2014), often with a particular emphasis on the incidence, role or contribution of outside board members (e.g., Fiegener et al., 2000; Deakins et al., 2001; Cowling, 2008; Boxer et al., 2012). In addition, research on corporate governance and entrepreneurship was subsequently fuelled in the early 1990s by the growing interest in private equity markets (Sapienza et al., 1996), in particular venture capitalists and their involvement and value added in the ventures in which they invest (e.g., Rosenstein, 1988; Rosenstein et al., 1993; Fried et al., 1998). Following this, there was also a general rise in research on start-ups and fast-growing firms in the 1990s, which opened up a range of issues and challenges related to corporate governance (Daily et al., 2002). These developments were also paralleled by a growing interest in research on corporate entrepreneurship (Guth and Ginsberg, 1990; Covin and Slevin, 1991), where some scholars addressed the critical role of the corporate governance system in supporting and facilitating innovation and entrepreneurial behavior in established corporations (e.g., Zahra, 1996; Zahra et al., 2000).

Research on corporate governance and entrepreneurship has over time come to include a wide range of studies with a common interest in the set of systems, principles and processes that govern and influence the direction and performance of firms in entrepreneurial settings. However, due to the multidisciplinary character of this stream of research, with contributions from management, finance, economics, accounting and law, it can potentially be problematic to acquire a comprehensive and detailed overview of the topic. Available studies seem to be scattered across a range of different disciplines, which suggest that findings are reported in a wide range of scholarly outlets. This, in turn, risks hampering scientific progress and limiting the accumulation of research findings within the field. The situation consequently calls for a systematic effort to collect and accumulate available research evidence to support the collection and dissemination of scholarly knowledge as well as a guide for future research.

Given this, the aim of this introductory chapter is to provide an overview of the current state-of-the-art research positioned in the intersection of corporate governance and entrepreneurship. This aim will be met by means of a systematic literature review (e.g., Pittaway, Holt \& Broad, 2014), where research in peer-reviewed academic journals will be identified, assessed and reported. Based on the review the chapter will then 
discuss the current state and possible future directions in this field of research.

The rest of the chapter is structured as follows. The next section will present details of the search methodology that has been used for identifying and analyzing research positioned in the intersection of corporate governance and entrepreneurship. This will be followed by an analysis and assessment of the current state of this stream of research with respect to main journal outlets, entrepreneurial settings, methodological approaches and empirical contexts. The chapter ends with a presentation of the chapters included in this volume with a discussion of how they explore and expand contemporary research on corporate governance and entrepreneurship.

\section{SEARCH METHODOLOGY}

The search methodology employed in this chapter has followed the general principles of a systematic literature review (e.g., Pittaway et al., 2014). This structured approach emphasizes the importance of describing the various steps undertaken in the review process. The transparent procedure in a systematic literature review has some notable advantages over traditional ad hoc reviews (Denyer and Tranfield, 2008), especially in areas that build on a highly diverse and multidisciplinary knowledge base. For example, it enhances validity, rigor and generalizability (Wang and Chugh, 2014) and also enables and opens up for reflection and integration (Pittaway et al., 2014). Following available guidelines, the systematic literature review in this chapter was structured in four action steps, as illustrated in Figure 1.1.

In the planning stage, the review objectives were defined in accordance with the overall aim of the chapter. This was followed by the development of a coding scheme to assemble and synthesize data about main journal outlets, entrepreneurial contexts, methodological approaches and empirical contexts. The coding scheme enabled systematic collection of relevant data in line with the objective of the review.

In the search stage, a number of bibliographical electronic databases were employed using the root search string "corporate governance* AND entrepreneurship*'. ABI/INFORM Complete, Business Source Elite and Scopus were found to provide greatest coverage of full-text articles. Combinations of the following keywords were then focused in the electronic search: Corporate Governance (or) Boards of Directors (or) Ownership (and) Entrepreneurship (or) Founder (or) Venture (or) Start up (or) Small Business (or) Small Corporation (or) Small Firm. Search terms were separated when consisting of multiple words.

All multiple entries were deleted as they substantially increased the 


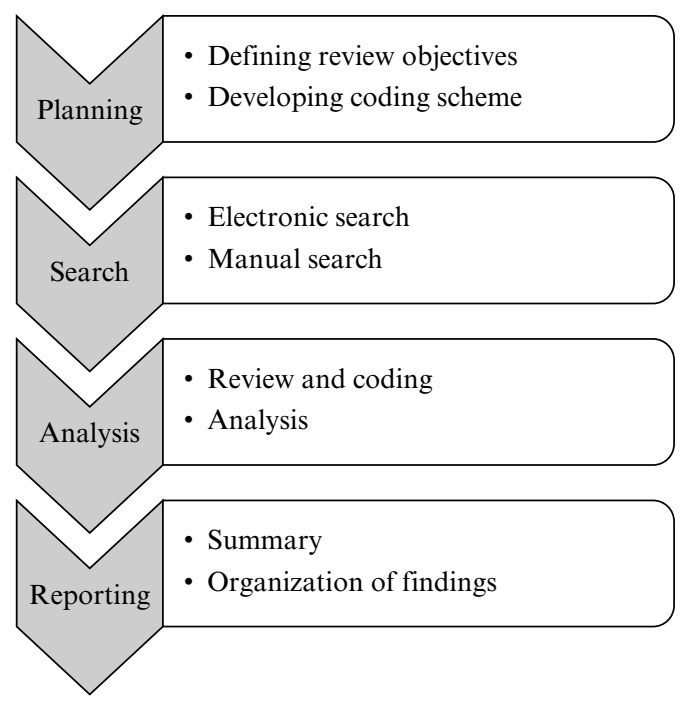

Figure 1.1 Steps in the systematic literature review

number of observed hits. The search was then limited to include only studies reported in peer-reviewed academic journals to be consistent with the review objectives. Studies that clearly lacked relevance were deleted. A narrative cross-referencing method based on a manual search of the bibliographies of all identified titles and abstracts supplemented the electronic search. The sample was then examined with respect to the review objective and aligned with the definitions expressed in the introduction. Entrepreneurship was in this examination broadly understood as the creation of future goods and services and/or the emergence of new economic activities, including the development and growth of new and small businesses and the characteristics and special problems of founders and entrepreneurs. Corporate governance was broadly understood as the set of systems, principles and processes by which an enterprise is controlled and directed. Articles that were judged as only marginally relevant for knowledge accumulation in the intersection of corporate governance and entrepreneurship were excluded. A sample of 122 articles published in international peer-reviewed academic journals remained after this screening. All identified articles were downloaded to enable full reading and analysis. A list of all articles included in the analysis is presented in Appendix 1.1.

In the analysis stage, the articles were reviewed and coded in accordance with the pre-made coding scheme. After a first round of coding a 
colleague was consulted for identifying and correcting coding errors. The resulting dataset was then used as an input in the analysis of the articles. In the final reporting stage, tables were created to illustrate the outcomes of the descriptive analysis as a basis for summarizing and organizing the findings.

\section{CORPORATE GOVERNANCE AND ENTREPRENEURSHIP: CURRENT STATES}

In this part an analysis and assessment of the current state of research in corporate governance and entrepreneurship is presented with respect to main journal outlets, entrepreneurial settings, methodological approaches and empirical contexts. Overall, the analysis confirms that research positioned in the intersection of corporate governance and entrepreneurship has grown considerably in the past two decades. There were five studies published in the 1980s, followed by 17 studies in the 1990s, and 60 studies in the 2000s. Between 2010 and 2016, there were 40 studies published. The 122 articles identified in the search were published in 60 different academic journals. These journals cover a wide number of academic disciplines, primarily related to business and management research. A list of all journals can be found in Appendix 1.2. A summary of the top ten journal outlets is provided in Figure 1.2.

More than half of the articles (54 percent) were published in the ten academic journals reported in Figure 1.2. Academic journals that focus on entrepreneurship and small businesses research dominate in terms of top outlets. The main scholarly outlet is Entrepreneurship Theory and Practice, but a significant number of contributions can also be found in journals such as Small Business Economics, Journal of Business Venturing, Entrepreneurship and Regional Development and Journal of Small Business and Enterprise Development. Three of the journals on the top ten list can be classified as field-specific outlets specifically devoted to corporate governance research: Corporate Governance: An International Review, Journal of Management and Governance and International Journal of Business Governance and Ethics. Two journals remain on the list. Of these, Journal of Management can be classified as a main management journal with a broad coverage of various topics, while Long Range Planning is a journal more specifically focused on strategic management research.

Research in the intersection of corporate governance and entrepreneurship includes a range of various entrepreneurial settings. The articles were in this respect classified with respect to the particular setting each study focused on. This procedure followed an abductive logic (e.g., Alvesson 


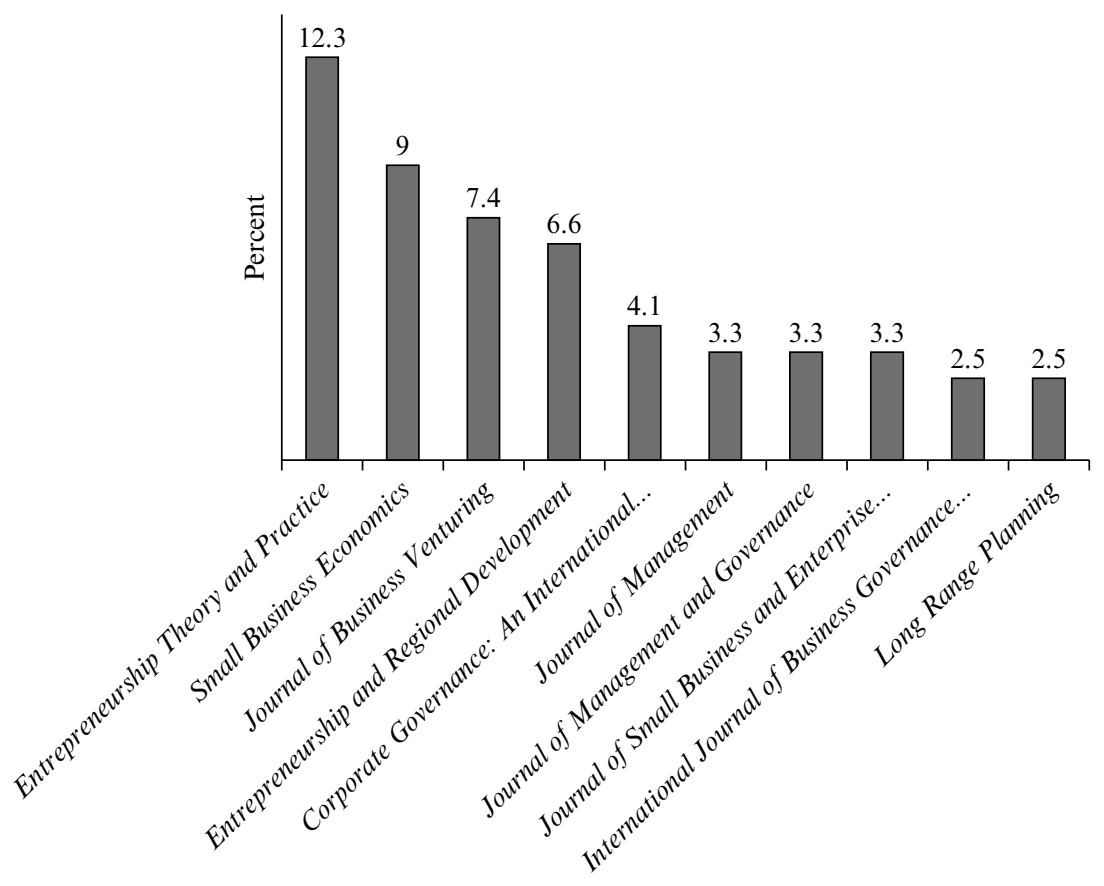

Figure 1.2 Top ten scholarly outlets

and Sköldberg, 2009), starting from preliminary conceptions based on pre-understanding and with the research purpose, framework and findings of each article then serving as inputs in the classification process. Potential new settings were identified, critically examined and potentially added as they emerged. Articles that addressed multiple settings were carefully screened and thereafter put in the category that best described their overall focus. Figure 1.3 provides a summary of the various entrepreneurial contexts studied in relation to the total number of studies.

Figure 1.3 suggests that research on corporate governance in small and medium-sized enterprises (SMEs) continues to dominate as this represents almost half of all studies (46.3 percent). A smaller but significant share of studies address corporate governance in start-ups and young firms (16.5 percent). Many of these show a particular interest in high-technology ventures. In addition, there have been notable scholarly interests in initial public offerings (IPOs) (10.7 percent) and VC-backed ventures ( 9.9 percent), which reflect the strong connection to issues of corporate governance in these contexts. Among the remaining studies there is a specific category of studies that focus on threshold firms (5 percent). 


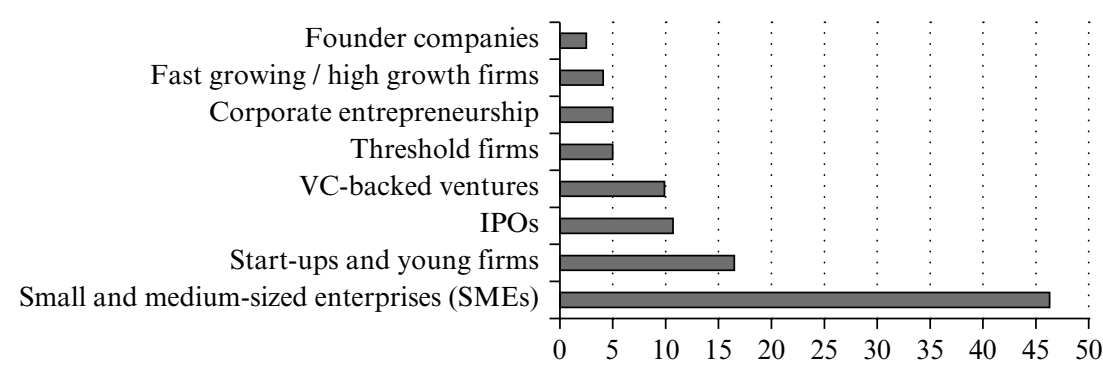

Figure 1.3 Entrepreneurial settings

Their commonality lies in that they address the evolution of corporate governance when firms grow and develop from 'entrepreneurial' to 'professional' organizations over the corporate life cycle. There is also a small but distinct stream of research on corporate governance in relation to corporate entrepreneurship (5 percent), primarily with a focus on how ownership and boards influence firms to be more or less entrepreneurial in their strategic behaviors and actions. Another small but distinct stream of research includes studies of corporate governance in fast-growing or high-growth firms (4.1 percent). Finally, a recent stream of studies also focuses on corporate governance in founder-led companies (2.1 percent) with a focus on comparing how founder versus family ownership influence firm performance.

Overall, it seems that studies in this field of research rely heavily on theories and frameworks that are used in mainstream corporate governance research (e.g., Gabrielsson and Huse, 2004; Yar Hamidi and Gabrielsson, 2014). Perhaps not surprisingly, the review shows that agency theory dominates with respect to applied theories. However, several studies use other theoretical frameworks typically found in corporate governance research, such as resource dependence theory, resource-based view of the firm, stewardship theory and institutional theory, sometimes in combination with or in contrast to agency theoretical reasoning. Other noteworthy theories applied in some of the studies are team production theory, imprinting theory and the attention-based view of the firm.

An explanation for the heavy reliance of theories and frameworks used in mainstream corporate governance research may be that many studies in the sample focus on entrepreneurial settings where the institutional arrangements that condition the structures and processes of corporate governance are relatively well defined, such as (mature) SMEs, IPOs, and even some larger publicly listed corporations, which represent a different institutional context compared to start-ups and younger 


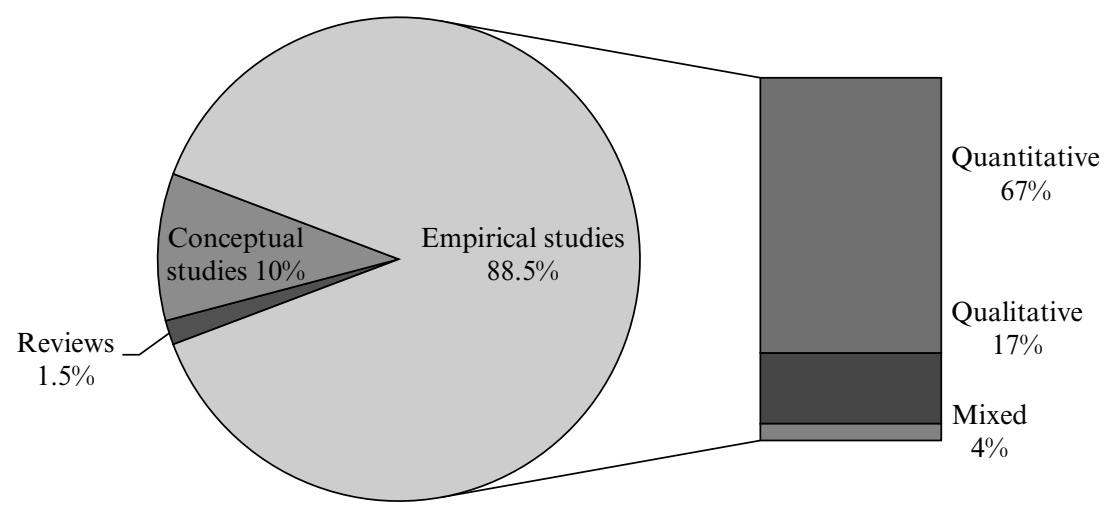

Figure 1.4 Types of methodological approach

ventures. In this respect, established theories used in mainstream corporate governance research seem to be both easy and relevant to apply in such settings.

The majority of studies are based on empirical research (88 percent). There were also a few conceptual studies (10 percent) and two reviews (e.g., Huse, 2000; Daily et al., 2002) found in the search. Of the empirical research the majority of studies employ quantitative methodological approaches (68 percent), often with data collected via questionnaires and using sophisticated statistical techniques to analyse the datasets. Much fewer but still a significant number of studies employ qualitative methodological approaches (17 percent). Interviews are the most common method of data collection among these studies. A much smaller number of studies (4 percent) use mixed methodologies in their research designs. A summary of the methodological approaches employed in research on corporate governance and entrepreneurship is presented in Figure 1.4.

A detailed review of the studies shows that most of them, about 60 percent, can be classified as 'outcome research' designed to explain effects of various corporate governance arrangements. There was also a relatively large share, about 35 percent, that can be classified as 'antecedent research' where studies focus on causes of corporate governance. Only a small share of the studies, about 5 percent, can be classified as 'characteristics research' that makes in-depth detailed examination and description to define and delimit phenomena and provide context to theory, without trying to determine cause-and-effect relationships or make predictions. Overall, this pattern is in line with the methodological approaches employed described in Figure 1.4.

The analysis was also directed towards identifying the empirical contexts 


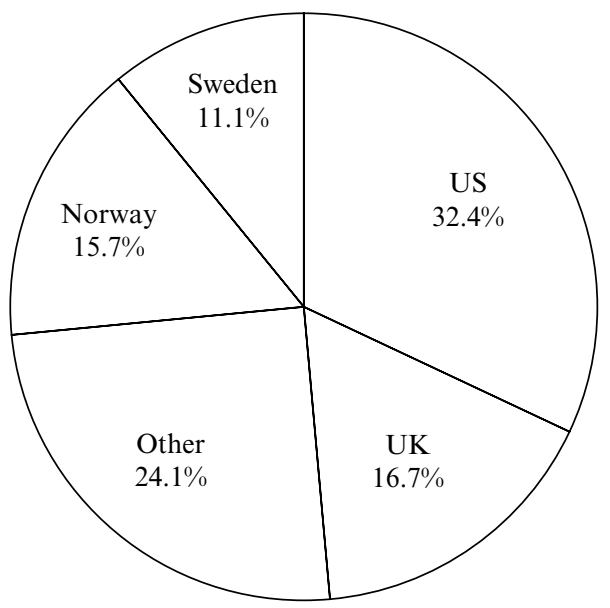

Figure 1.5 Top countries studied

studied. The large majority of the empirical studies (96 percent) present data from a single country. Only a handful of studies (e.g., Borch and Huse, 1993; Huse, 1990; Sapienza et al., 1996; Filatotchev et al., 2005; Scholes et al., 2007; Voordeckers et al., 2014; Durst and Henschel, 2014) compare and analyse data from multiple countries. With respect to countries, the United States (US) is represented in 32.4 percent of all studies. After this comes the United Kingdom (UK) (16.7 percent) and Norway (15.7 percent), followed by Sweden (11.1 percent). Overall, the findings suggest that a dominant portion of available scholarly research on corporate governance and entrepreneurship is embedded in either AngloAmerican or Scandinavian models of corporate governance, each with its particular features and institutional arrangements. The top countries studied in research on corporate governance and entrepreneurship are presented in Figure 1.5.

Some final remarks can be made about the current state of research in corporate governance and entrepreneurship based on the assessment and analysis provided in this chapter. Overall, the findings suggest that research positioned in the intersection of corporate governance and entrepreneurship has become a relatively well-established area of scholarly inquiry. The search identified a large number of studies, of which 122 were assessed in the screening stage as relevant for further consideration with respect to the accumulation of scholarly knowledge within this stream of research. While the available research evidence is scattered across 60 different academic journals, about half of these studies appear in ten of them. These top ten journals are all established and well recognized by scholars 
within their specific fields of research. In this respect, the research field presents favorable conditions with respect to the possibility for scholars to continue to accumulate and develop scholarly knowledge on corporate governance and entrepreneurship by reading and relating to each other's work. Moreover, there seems to be ample opportunities for publishing research on corporate governance and entrepreneurship in academic journals of high quality.

The findings also suggest that research positioned in the intersection of corporate governance and entrepreneurship often focus on settings where the institutional arrangements that condition the structures and processes of corporate governance are relatively well defined, in particular SMEs, but also IPOs and larger publicly listed corporations. In this respect, studies often rely on established theories used in mainstream corporate governance research, where agency theory seems to be the dominant theoretical framework. Moreover, the findings suggest that the large majority of studies are empirical, and most of them rely on first-hand data that has been collected for the specific purpose of the research. Quantitative approaches dominate, and the data are typically analysed using rigorous statistical analyses. Most of the empirical research is conducted in the US, the UK or Scandinavia (in particular Norway and Sweden), while studies in other institutional settings are scarcer. In this respect, there seem to be ample opportunities to advance scholarly knowledge on governance and entrepreneurship by expanding efforts towards geographical and organizational settings that so far have been less studied in this stream of research.

\section{CORPORATE GOVERNANCE AND ENTREPRENEURSHIP: FUTURE DIRECTIONS}

The chapters in this volume provide a unique collection of research addressing issues of corporate governance in various entrepreneurial settings, including start-ups, owner-managed firms, fast-growing firms and IPOs, as well as how corporate governance and board leadership is associated with entrepreneurship and innovation in small and large established companies. The various chapters span a wide range of topics, methodologies and levels of analysis, all designed to contribute to the advancements of the understanding of corporate governance and entrepreneurship within and across different organizational and geographical settings.

The book is divided into four parts. Part I contains discussions about research on corporate governance and entrepreneurship as a research field. The present chapter has provided an overview of the current 
state-of-the-art research positioned in the intersection of the corporate governance and entrepreneurship disciplines. In Chapter 2, Jonas Gabrielsson and Morten Huse continue with a review of the historical and intellectual roots of resource dependence theory and agency theory, two dominant theories in research of boards and corporate governance, with a particular focus on how they have been applied in studies of entrepreneurial firms.

Part II focuses on corporate governance in start-ups and early-stage ventures. It starts with Chapter 3, where Eythor Jonsson examines the roles and key tasks performed by advisory boards in start-ups and growthoriented companies from the perspective of contemporary corporate governance literature. Empirical findings from the advisory board program at Copenhagen Business School (CBS) in Denmark suggest that advisory boards play an important role for their direction and performance. However, as the underlying rationale for advisory boards is different from legal boards, the author also identifies opportunities to continue to extend and develop contemporary conceptualizations to better explain what advisory boards do and why they are valuable for entrepreneurial firms. In Chapter 4, Till Talaulicar introduces an input-mediator-outcome model implemented and developed from group theory to analyze and substantiate the effects of various structural arrangements of the organization of top management teams (TMTs) in high-tech venture firms. He discusses how installing either a command or a collegial model of TMT organization influences behavioral, cognitive and affective group processes, which in turn influence the comprehensiveness and speed of TMT decision-making. In the following chapter (Chapter 5), Ekaterina Bjornali reviews and synthesizes scholarly research on boards in high-tech start-ups as a means to accumulate and discuss state-of-the-art knowledge in the field and to identify future research directions. Overall, the chapter identifies research on boards as an extension of the top management team in high-tech startups as a promising, yet relatively unexplored area of scholarly inquiry. In Chapter 6, Elien Vandenbroucke and Mirjam Knockaert elaborate further on this topic by examining how TMT and outside board human capital affects innovation speed in a sample of Belgian early-stage high-tech firms. In this respect, they emphasize the need to consider the outside board as a part of the extended TMT as these are not standalone entities in an early-stage high-tech context. In Chapter 7, Stefano Bonini and Vincenzo Capizzi present a review of the main theoretical contributions and empirical results on how private equity investors influence corporate governance in young and fast-growing companies.

Part III turns attention to corporate governance in small and mediumsized enterprises (SMEs). Susanne Durst and Julia Brunhold open in 
Chapter 8 with addressing how beliefs and practices of small firm ownermanagers in the Rhine Valley region are reflected in their governance structures. As such, they examine what decision-makers understand by the term 'corporate governance' and which governance methods and procedures are implemented by the management of these firms. In Chapter 9, Daniel Pittino, Paola Mazzurana and Francesca Visintin examine the adoption of formal mechanisms in the governance of strategic alliances established by entrepreneurial firms in the north-east of Italy. In the study they identify that family business status plays a role in explaining interorganizational arrangements, but also that this is contingent on the size of the firm. In Chapter 10, Daniel Yar Hamidi and Jonas Gabrielsson present a study of how board chairpersons may develop innovationpromoting boards in small entrepreneurial firms in Sweden. The chapter offers insights into board development processes in such firms and identifies and describes the board leadership practices that experienced board chairpersons recommend for promoting innovation in this setting.

Part IV focuses attention on corporate governance in fast-growing firms and IPOs. In Chapter 11, Teresa Nelson and Huseyin Leblebici present and articulate an engagement theory of governance for high-growth entrepreneurial ventures. Embedded in a dynamic organizational systems view, the chapter discusses how governance relationships emerge and evolve over time during the IPO process in a negotiated organizational field of problem-solving and decision-making. In Chapter 12, Asma FattoumGuedri and Frédéric Delmar examine the implementation of defensive mechanism by founder-chief executive officers (CEOs) and non-founderCEOs in French IPOs. The chapter develops a theoretical framework that explains why founder-CEOs are more likely than non-founder-CEOs to use defensive mechanisms at IPO, and the empirical results confirm the additive effects of dual class shares, pyramid control structures and voting pact agreements in shielding CEO shareholders from undesired change of control. In Chapter 13 Marita Blomkvist and Mari Paananen examine and compare differences in the quality of financial reporting between Gazelles and Non-Gazelles in Sweden. The findings imply that the quality of financial accounting is of less importance; however, corporate governance mechanisms that influence financial reporting quality have an indirect impact on the cost of debt.

Finally, Part V focuses on corporate governance and corporate entrepreneurship. Elin Smith and Sven-Olof Collin start in Chapter 14 by exploring the intertwinement between the disciplining (governance) side and the enabling (entrepreneurship) side of the firm. In the chapter they propose that such a theory needs to acknowledge the distribution of property rights and liabilities among participants of different organizational 
forms. Based on Swedish data they discuss how corporate entrepreneurship can be triggered by different governance mechanisms and their specific formations. In Chapter 15, Seppo Laukkanen, Martin Lindell and Anssi Vanjoki examine how corporate governance and leadership can advance entrepreneurship in a large corporation. Based on three Nokia innovation cases, they provide insights into how corporate governance and corporate entrepreneurship interact via organizational culture, strategy, administrative frameworks and sponsoring of entrepreneurial activities, as well as through critical decisions on resources.

\section{REFERENCES}

Alvesson, M. and Sköldberg, K. (2009) Reflexive Methodology: New Vistas for Qualitative Research: Second Edition, London: Sage Publications.

Bednar, M.K. (2012) Watchdog or lapdog? A behavioral view of the media as a corporate governance mechanism, Academy of Management Journal, 55, 131-150.

Bennett, R.J. and Robson, P.J.A. (2004) The role of boards of directors in small and medium-sized firms, Journal of Small Business and Enterprise Development, 11(1), 95-113.

Beusenlinck, C. and Manigart, S. (2007) Financial reporting quality in private equity backed companies: The impact of ownership concentration, Small Business Economics, 29(3), 261-274.

Borch, O.J. and Huse, M. (1993) Informal strategic networks and boards of directors, Entrepreneurship Theory and Practice, 18(1), 23-36.

Boxer, R., Berry, A. and Perren, L. (2012) Differing perceptions of non-executive directors' roles in UK SMEs: Governance conundrum or cultural anomaly, Accounting Forum, 36(1), 38-50.

Castaldi, R. and Wortman, M.S. (1984) Board of directors in small corporations: An untapped resource, American Journal of Small Business, 9(2), 1-11.

Cohen, J., Krishnamoorthyn, G. and Wright, A. (2010) Corporate governance in the postSarbanes-Oxley era: Auditors' experiences, Contemporary Accounting Research, 27(3), 751-786.

Conyon, M.J. (2006) Executive compensation and incentives, Academy of Management Perspectives, 20, 25-44.

Covin, J.G. and Miles, M.P. (1999) Corporate entrepreneurship and the pursuit of competitive advantage, Entrepreneurship Theory and Practice, 23(3), 47-63.

Covin, J.G. and Slevin, D.P. (1991) A conceptual model of entrepreneurship as firm behavior, Entrepreneurship Theory and Practice, 16(1), 7-25.

Cowling, M. (2003) Productivity and corporate governance in smaller firms, Small Business Economics, 20(4), 335-344.

Daily, C.M., Dalton, D.R. and Cannella, A.A. (2003) Corporate governance: Decades of dialogue and data, Academy of Management Review, 28(3), 371-382.

Daily, C.M., McDougall, P.P., Covin, J.G. and Dalton, D.R. (2002) Governance and strategic leadership in entrepreneurial firms, Journal of Management, 28(3), 387-412.

Davidsson, P. (1991) Continued entrepreneurship: Ability, need, and opportunity as determinants of small firm growth, Journal of Business Venturing, 6(6), 405-429.

Davidsson, P. (1995) Culture, structure and regional levels of entrepreneurship, Entrepreneurship and Regional Development, 7, 41-62.

Deakins, D., O’Neill, E. and Mileham, P. (2001) Chief executive officers and nonexecutive directors: Their relationships in small companies, Environment and Planning C: Government and Policy, 19(3), 355-372. 
Delmar, F., Davidsson, P. and Gartner, W. (2003) Arriving at the high-growth firm, Journal of Business Venturing, 18(2), 189-216.

Denyer, D. and Tranfield, D. (2008) Producing a systematic review, in Buchanan, D. and Bryman, A. (eds), Handbook of Organisational Research Methods, London: Sage, pp. 671-689.

Durst, S. and Henschel, T. (2014) Governance in small firms: A country comparison of current practices, International Journal of Entrepreneurship and Small Business, 21(1), 16-32.

Fiegener, M.K., Brown, B.M., Dreux IV, D.R. and Dennis Jr, W.J. (2000) The adoption of outside boards by small private US firms, Entrepreneurship and Regional Development, 12(4), 291-310.

Filatotchev, I., Chahine, S., Wright, M. and Arberk, M. (2005) Founders' characteristics, venture capital syndication and governance in entrepreneurial IPOs, International Entrepreneurship and Management Journal, 1(4), 419-439.

Forbes, D.P. and Milliken, F.J. (1999) Cognition and corporate governance: Understanding boards of directors as strategic decision making groups, Academy of Management Review, 24, 489-505.

Fried, V.H., Bruton, G.D. and Hisrich, R.D. (1998) Strategy and the board of directors in venture capital-backed firms, Journal of Business Venturing, 13, 493-503.

Ford, R.H. (1988) Outside directors and the privately-owned firm: Are they necessary?, Entrepreneurship Theory and Practice, 13(1), 49-57.

Gabrielsson, J. and Huse, M. (2002) The venture capitalist and the board of directors in SMEs: Roles and processes, Venture Capital, 4(2), 125-146.

Gabrielsson, J. and Huse, M. (2004) Context, behavior, and evolution: Challenges in research on boards and governance, International Studies of Management and Organization, 34(3), $11-36$.

Gabrielsson, J. and M. Huse (2010) Governance theory: Origins and implications for researching boards and governance in entrepreneurial firms, in Landström, $\mathrm{H}$. and Lohrke, F. (eds), The Historical Foundations of Entrepreneurship Research, Cheltenham, UK and Northampton, MA, USA: Edward Elgar Publishing.

Gartner, W.B. (1985) A conceptual framework for describing the phenomenon of new venture creation, Academy of Management Review, 10, 696-706.

Garvin, D.A. and Levesque, L.C. (2006) Meeting the challenge of corporate entrepreneurship, Harvard Business Review, 84(10), 102-112.

Giroud, X. and Mueller, H. (2011) Corporate governance, product market competition, and equity prices, Journal of Finance, 66(2), 563-600.

Guth, W. and Ginsberg, A. (1990) Guest editor's introduction: Corporate entrepreneurship, Strategic Management Journal, Summer Special Issue, 11, 5-15.

Huse, M. (1990) Board composition in small enterprises, Entrepreneurship and Regional Development, 2(4), 363-373.

Huse, M. (1994) Board-management relations in small firms: The paradox of simultaneous independence and interdependence, Small Business Economics, 6(1), 55-72.

Huse, M. (2000) Boards in SMEs: A review and research agenda, Entrepreneurship and Regional Development, 12(4), 271-290.

Judge, W.Q., Weber, T. and Muller-Kahle, M. (2012) What are the correlates of interdisciplinary research impact? The case of corporate governance research, Academy of Management Learning and Education, 11(1), 82-98.

Kearney, C., Hisrich, R. and Roche, F. (2008) A conceptual model of public sector corporate entrepreneurship, International Entrepreneurship and Management Journal, 4(3), 295-313.

La Porta, R., Lopez-de-Silanes, B., Shleifer, A. and Vishny, R. (2000) Investor protection and corporate governance, Journal of Financial Economics, 58(1-2), 3-27.

Landström, H. (2010) Pioneers in Entrepreneurship and Small Business Research, New York: Springer.

Mace, M.L. (1948) The Board of Directors in Small Corporations, Boston, MA: Graduate School of Business Administration, Harvard University, published dissertation. 
Mace, M.L. (1971) Directors: Myth and Reality, Boston, MA: Harvard University.

Mace, M.L. (1972) The president and the board of directors, Harvard Business Review, March-April, 37-49.

Markman, G.D., Balkin, D.B. and Schjoedt, L. (2001) Governing the innovation process in entrepreneurial firms, Journal of High Technology Management Research, 12, 273-293.

Morris, M.H. and Jones, F.F. (1999) Entrepreneurship in established organizations: The case of the public sector, Entrepreneurship Theory and Practice, 24, 71-91.

Nash, J.M. (1988) Boards of privately held companies: Their responsibilities and structure, Family Business Review, 1(3), 263-269.

Pedersen, T. and Thomsen, S. (2003) Ownership structure and value of the largest European firms: The importance of ownership identity, Journal of Management and Governance, 7, $27-55$.

Pittaway, L., Holt, R. and Broad, J. (2014) Synthesising knowledge in entrepreneurship research: The role of systematic literature reviews, in Chell, E. and Karataş-Özkan, M. (eds), Handbook of Research on Small Business and Entrepreneurship, Cheltenham, UK and Northampton, MA, USA: Edward Elgar Publishing, pp. 83-105.

Rosenstein, J. (1988) The board and strategy: Venture capital and high technology, Journal of Business Venturing, 3(2), 159-170.

Rosenstein, J., Bruno, A.V., Bygrave, W.D. and Taylor, N.T. (1993) The CEO, venture capitalists, and the board, Journal of Business Venturing, 8, 99-113.

Sapienza, H.J., Manigart, S. and Vermeir, W. (1996) Venture capitalist governance and value added in four countries, Journal of Business Venturing, 11(6), 439-469.

Scholes, L.M., Wright, M., Westhead, P., Burrows, A. and Bruining, H. (2007) Information sharing, price negotiation and management buy-outs of private family-owned firms, Small Business Economics, 29(3), 329-349.

Sinani, E., Stafsudd, A., Thomsen, S., Edling, C. and Randøy, T. (2008) Corporate governance in Scandinavia: Comparing networks and formal institutions, European Management Review, 5(1), 27-40.

Thomsen, S. and Conyon, M. (2012) Corporate Governance: Mechanisms and Systems, New York: McGraw-Hill.

Tihanyi, L., Graffin, S. and George, G. (2014) From the editors: Rethinking governance in management research, Academy of Management Journal, 57(6), 1535-1543.

Voordeckers, W., Van Gils, A., Gabrielsson, J., Politis, D. and Huse, M. (2014) Board structures and board behaviour: A cross-country comparison of privately held SMEs in Belgium, the Netherlands and Norway, International Journal of Business Governance and Ethics, 9(2), 197-219.

Wang, C. and Chugh, H. (2014) Entrepreneurial learning: Past research and future challenges, International Journal of Management Reviews, 16(1), 24-61.

Yar Hamidi, D. and Gabrielsson, J. (2014) Developments and trends in research on board leadership: A systematic literature review, International Journal of Business Governance and Ethics, 9(3), 243-268.

Zahra, S.A. (1996) Governance, ownership and corporate entrepreneurship: The moderating effect of industry technological opportunities, Academy of Management Journal, 39(6), 1713-1735.

Zahra, S., Neubaum, D.C. and Huse, M. (2000) Entrepreneurship in medium-size companies: Exploring the effects of ownership and governance systems, Journal of Management, 26(5), 947-976.

\section{APPENDIX 1.1: ARTICLES IDENTIFIED IN THE SYSTEMATIC LITERATURE REVIEW}

Aaboen, L., Lindelöf, P., von Koch, C. and Löfsten, H. (2006) Corporate governance and performance of small high-tech firms in Sweden, Technovation, 26, 955-968.

Abor, J. and Biepke, N. (2007) Corporate governance, ownership structure and performance 
of SMEs in Ghana: Implications for financing opportunities, Corporate Governance: The International Journal of Effective Board Performance, 7(3), 288-300.

Ahn, M. (2014) Enhancing corporate governance in high-growth entrepreneurial firms, International Journal of Innovation and Technology Management, 11(6), 1-16.

Albu, N. and Mateescu, R.A. (2015) The relationship between entrepreneurship and corporate governance: The case of Romanian listed companies, Amfiteatru Economic, 17(38), 44-59.

Arthurs, J.D., Busenitz, L.W., Hoskisson, R.E. and Johnson, R. (2009) Firm-specific human capital and governance in IPO firms: Addressing agency and resource dependence concerns, Entrepreneurship Theory and Practice, 33(4), 845-865.

Audretsch, D.B. and Lehmann, E. (2006) Entrepreneurial access and absorption of knowledge spillovers: Strategic board and managerial composition for competitive advantage, Journal of Small Business Management, 44(2), 155-166.

Belghitar, Y. and Khan, J. (2013) Governance mechanisms, investment opportunity set and SMEs cash holdings, Small Business Economics, 40(1), 59-72.

Bennett, R.J. and Robson, P.J.A. (2004) The role of boards of directors in small and medium-sized firms, Journal of Small Business and Enterprise Development, 11(1), 95-113.

Berry, A. and Perren, L. (2001) The role of non-executive directors in UK SMEs, Journal of Small Business and Enterprise Development, 8(1), 159-173.

Beusenlinck, C. and Manigart, S. (2007) Financial reporting quality in private equity backed companies: The impact of ownership concentration, Small Business Economics, 29(3), 261-274.

Bishara, N.D. (2011) Governance and corruption constraints in the Middle East: Overcoming the business ethics glass ceiling, American Business Law Journal, 48(2), 227-283.

Bjornåli, E.S. and Aspelund, A. (2012) The role of the entrepreneurial team and the board of directors in the internationalization of academic spin-offs, Journal of International Entrepreneurship, 10(4), 350-377.

Bjornåli, E. and Gulbrandsen, M. (2010) Exploring board formation and evolution of board composition in academic spin-offs, Journal of Technology Transfer, 35(1), 92-112.

Bjornåli, E.S., Knockaert, M. and Erikson, T. (2016) The impact of top management team characteristics and board service involvement on team effectiveness in high-tech start-ups, Long Range Planning, doi: 10.1016/j.1rp.2015.12.014.

Block, J.H., Jaskiewicz, P. and Miller, D. (2011) Ownership versus management effects on performance in family and founder companies: A Bayesian reconciliation, Journal of Family Business Strategy, 2(4), 232-245.

Borch, O.J. and Huse, M. (1993) Informal strategic networks and boards of directors, Entrepreneurship Theory and Practice, 18(1), 23-36.

Boxer, R., Berry, A. and Perren, L. (2012) Differing perceptions of non-executive directors' roles in UK SMEs: Governance conundrum of cultural anomaly, Accounting Forum, 36(1), 38-50.

Boxer, R., Perren, L. and Berry, A. (2013) SME top management team and non-executive director cohesion: Precarious equilibrium through information asymmetry, Journal of Small Business and Enterprise Development, 20(1), 55-79.

Brunninge, O. and Nordqvist, M. (2004) Ownership structure, board composition and entrepreneurship: Evidence from family firms and venture-capital backed firms, International Journal of Entrepreneurial Behaviour and Research, 10(1-2), 85-105.

Brunninge, O., Nordqvist, M. and Wiklund, J. (2007) Corporate governance and strategic change in SMEs: The effects of ownership, board composition and top management teams, Small Business Economics, 29(3), 295-308.

Calabró, A. and Mussolino, D. (2013) How do boards of directors contribute to family SME export intensity? The moderating role of formal and informal governance mechanisms, Journal of Management and Governance, 17(2), 363-403.

Calabró, A., Mussolino, D. and Huse, M. (2009) The role of board of directors in the internationalization process of small and medium sized businesses, International Journal of Globalisation and Small Business, 3(4), 393-411. 
Castaldi, R. and Wortman, M.S. (1984) Board of directors in small corporations: An untapped resource, American Journal of Small Business, 9(2), 1-11.

Certo, S.T., Daily, C.M. and Dalton, D.R. (2001) Signalling firm value through board structure: An investigation of initial public offerings, Entrepreneurship Theory and Practice, 26(2), 33-50.

Chahine, S., Filatotchev, I. and Zahra, S.A. (2011) Building perceived quality of founderinvolved IPO firms: Founder's effects on board selection and stock market performance, Entrepreneurship Theory and Practice, 35(2), 319-335.

Chahine, S. and Saade, S. (2011) Shareholder rights and the effect of the origin of venture capital firms on the underpricing of US IPOs, Corporate Governance: An International Review, 19(6), 601-621.

Charas, S. and Perelli, S. (2013) Threats to board stability: Understanding SME director behavior, Journal of Disclosure and Governance, 10(2), 175-191.

Christy, J.A. (2013) Do board characteristics influence the shareholders' assessment of risk for small and large firm, Abacus, 49(2), 161-196.

Clarysse, B., Knockaert, M. and Lockett, A. (2007) Outside board members in high-tech start-ups, Small Business Economics, 29(3), 243-259.

Colin, B. (2001) The role of non-executive directors in high-tech SMEs, Corporate Governance: The International Journal of Effective Board Performance, 1(2), 34-36.

Colombo, M.G., Croce, A. and Murtinu, S. (2014) Ownership structure, horizontal agency costs and the performance of high-tech entrepreneurial firms, Small Business Economics, 42(2), 265-282.

Coulson-Thomas, C. (2007) SME directors and boards: The contribution of directors and boards to the growth and development of small and medium-sized enterprises (SMEs), International Journal of Business Governance and Ethics, 3(3), 250-261.

Cowling, M. (2003) Productivity and corporate governance in smaller firms, Small Business Economics, 20(4), 335-344.

Cowling, M. (2008) Small firm CEOs and outside directorships: Tenure, demonstration and synergy effects, Manchester School, 76(2), 160-179.

Daily, C.M. and Dalton, D.R. (1992) The relationship between governance structure and corporate performance in entrepreneurial firms, Journal of Business Venturing, 7(5), 375-386.

Daily, C.M. and Dalton, D.R. (1993) Board of directors leadership and structure: Control and performance implications, Entrepreneurship Theory and Practice, 17(3), 65-81.

Daily, C.M., McDougall, P.P., Covin, J.G. and Dalton, D.R. (2002) Governance and strategic leadership in entrepreneurial firms, Journal of Management, 28(3), 387-412.

Deakins, D., O'Neill, E. and Mileham, P. (2000) The role and influence of external directors in small and entrepreneurial companies: Some evidence on VC and non-VC appointed external directors, Venture Capital, 2, 111-127.

Deakins, D., O'Neill, E. and Mileham, P. (2000) Insiders vs. outsiders: Director relationships in small, entrepreneurial companies, Enterprise and Innovation Management Studies, 1(2), $175-186$.

Deakins, D., O'Neill, E. and Mileham, P. (2001) Chief executive officers and nonexecutive directors: Their relationships in small companies, Environment and Planning $C$ : Government and Policy, 19(3), 355-372.

Deutsch, Y. and Ross, T.W. (2003) You are known by the directors you keep: Reputable directors as signaling mechanism for young firms, Management Science, 49(8), $1003-1027$.

Durst, S. and Henschel, T. (2014) Governance in small firms: A country comparison of current practices, International Journal of Entrepreneurship and Small Business, 21(1), $16-32$.

Faraq, H., Mallin, C. and Ow-Kong, K. (2014) Governance, ownership, and performance of entrepreneurial IPOs in AIM companies, Corporate Governance: An International Review, 22(2), 100-115.

Fiegener, M.K. (2005) Determinants of board participation in the strategic decisions of small corporations, Entrepreneurship Theory and Practice, 29(5), 627-650. 
Fiegener, M.K., Brown, B.M., Dreux IV, D.R. and Dennis Jr, W.J. (2000) The adoption of outside boards by small private US firms, Entrepreneurship and Regional Development, 12(4), 291-310.

Filatotchev, I., Chahine, S., Wright, M. and Arberk, M. (2005) Founders' characteristics, venture capital syndication and governance in entrepreneurial IPOs, International Entrepreneurship and Management Journal, 1(4), 419-439.

Finkle, T.A. (1998) The relationship between boards of directors and initial public offerings in the biotechnology industry, Entrepreneurship Theory and Practice, 22(3), 627-650.

Forbes, D.P., Korsgaard, M.A. and Sapienza, H.J. (2010) Financing decisions as a source of conflict in venture boards, Journal of Business Venturing, 25(6), 579-592.

Ford, R.H. (1988) Outside directors and the privately-owned firm: Are they necessary?, Entrepreneurship Theory and Practice, 13(1), 49-57.

Fortin, R. and Roth, G. (2010) Small firm governance and analyst following, Academy of Accounting and Financial Studies Journal, 14(2), 47-57.

Fried, V.H., Bruton, G.D. and Hisrich, R.D. (1998) Strategy and the board of directors in venture capital-backed firms, Journal of Business Venturing, 13, 493-503.

Gabrielsson, J. (2007a) Boards of directors and entrepreneurial posture in medium-size companies: Putting the board demography approach to a test, International Small Business Journal, 25(5), 511-537.

Gabrielsson, J. (2007b) Correlates of board empowerment in small companies, Entrepreneurship Theory and Practice, 31(5), 687-711.

Gabrielsson, J. and Huse, M. (2002) The venture capitalist and the board of directors in SMEs: Roles and processes, Venture Capital, 4(2), 125-146.

Gabrielsson, J. and Politis, D. (2007) The impact of board governance on firm-level entrepreneurship in small technology based firms, ICFAI Journal of Corporate Governance, 6(3), 43-60.

Gabrielsson, J. and Winlund, H. (2000) Boards of directors in small and medium-sized industrial firms: examining the effects of the board's working style on board task performance, Entrepreneurship and Regional Development, 12(4), 311-330.

Garg, S. (2013) Venture boards: Distinctive monitoring and implications for firm performance, Academy of Management Review, 38(1), 90-108.

Gedajlovic, E., Lubatkin, M.H. and Schulze, W.S. (2004) Crossing the threshold from founder management to professional management: A governance perspective, Journal of Management Studies, 41(5), 899-912.

George, G., Wiklund, J. and Zahra, S. (2005) Ownership and the internationalization of small firms, Journal of Management, 31(2), 210-233.

George, G., Wood, D.R. and Khan, R. (2001) Networking strategy of boards: Implications for small and medium-sized enterprises, Entrepreneurship and Regional Development, 13(3), 269-285.

Gill, A.S., Mand, H.S. and Mathur, N. (2012) Corporate governance and the growth of small business service firms in India, International Research Journal of Finance and Economics, $96,113-123$.

Gill, A.S., Biger, N., Mand, H.S. and Shah, C. (2012) Corporate governance and capital structure of small business service firms in India, International Journal of Economics and Finance, 4(8), 83-92.

Gnan, L., Montemerlo, D. and Huse, M. (2015) Governance systems in family SMEs: The substitution effects between family councils and corporate governance mechanisms, Journal of Small Business Management, 53(2), 355-381.

Grundei, J. and Talaulicar, T. (2002) Company law and corporate governance of start-ups in Germany: Legal stipulations, managerial requirements, and modification strategies, Journal of Management and Governance, 6(1), 1-27.

Huse, M. (1990) Board composition in small enterprises, Entrepreneurship and Regional Development, 2(4), 363-373.

Huse, M. (1993) Relational norms as a supplement of neo-classical understanding of directorates, Journal of Socio-Economics, 22(3), 219-240. 


\section{Handbook of research on corporate governance and entrepreneurship}

Huse, M. (1994) Board-management relations in small firms: The paradox of simultaneous independence and interdependence, Small Business Economics, 6(1), 55-72.

Huse, M. (1998) Researching the dynamics of board-stakeholder relations, Long Range Planning, 31, 218-226.

Huse, M. (2000) Boards in SMEs: A review and research agenda, Entrepreneurship and Regional Development, 12(4), 271-290.

Huse, M. and Zattoni, A. (2008) Trust, firm life cycle, and actual board behavior: Evidence from 'one of the lads' in the board of three small firms, International Studies of Management and Organization, 38(3), 71-97.

Ingley, C.B. and McCaffrey, K. (2007) Effective governance for start-up companies: Regarding the board as a strategic resource, International Journal of Business Governance and Ethics, 3(3), 308-329.

Jaskiewicz, P., Block, J.H., Combs, J.G. and Miller, D. (2015) The effects of founder and family ownership on hired CEOs' incentives and firm performance, Entrepreneurship Theory and Practice, 35(2), 319-335.

Jaskiewicz, P., Block, J.H., Miller, D. and Combs, J.G. (2014) Founder versus family owners' impact on pay dispersion among non CEO top managers: Implications for firm performance, Journal of Management, doi: 10.1177/0149206314558487.

Johannisson, B. and Huse, M. (2000) Recruiting outside board members in the small family business: An ideological challenge, Entrepreneurship and Regional Development, 12(4), 353-378.

Klein, P.G. (1999) Entrepreneurship and corporate governance, Quarterly Journal of Austrian Economics, 2(2), 19-42.

Knockaert, M., Bjornali, E.S. and Erikson, T. (2015) Joining forces: Top management team and board chair characteristics as antecedents of board service involvement, Journal of Business Venturing, 30(3), 420-435.

Knockaert, M. and Ucbasaran, D. (2013) The service role of outside boards in high tech start-ups: A resource dependency perspective, British Journal of Management, 24(1), 69-84.

Kroll, M., Walters, B.A. and Le, S. (2007) The impact of board composition and top management team ownership structure on post-IPO performance in young entrepreneurial firms, Academy of Management Journal, 50, 1198-1216.

Lappalainen, J. and Niskanen, M. (2009) Does board composition and ownership structure affect firm growth? Evidence from Finnish SMEs, Research in Economics and Business Central and Eastern Europe, 1(1), 66-83.

Lappalainen, J. and Niskanen, M. (2012) Financial performance of SMEs: Impact of ownership structure and board composition, Management Research Review, 35(11), 1088-1108.

Le, S., Kroll, M. and Walters, B.A. (2012) The influence of board composition on top management team industry- and firm-specific human capital in young IPO firms, Journal of Managerial Issues, 24, 412-432.

Le, S., Kroll, M. and Walters, B.A. (2013) Outside directors' experience, TMT firm-specific human capital, and firm performance in entrepreneurial IPO firms, Journal of Business Research, 66, 533-539.

Lynall, M.D., Golden, B.R. and Hillman A.J. (2003) Board composition from adolescence to maturity: A multitheoretic view, Academy of Management Review, 28(3), 416-431.

Machold, S., Huse, M., Minichilli, A. and Nordqvist, M. (2011) Board leadership and strategy involvement in small firms: A team production approach, Corporate Governance: An International Review, 19(4), 368-382.

Markman, G.D., Balkin, D.B. and Schjoedt, L. (2001) Governing the innovation process in entrepreneurial firms, Journal of High Technology Management Research, 12, 273-293.

McMahon, R.G.P. (2007) Ownership structure, business growth and financial performance amongst SMEs: From Australia's business longitudinal survey, Journal of Small Business and Enterprise Development, 14(3), 458-477.

Miller, D. and Le-Breton Miller, I. (2011) Governance, social identity, and entrepreneurial orientation in closely held public companies, Entrepreneurship Theory and Practice, 35(5), 1051-1076. 
Minichilli, A. and Hansen, C. (2007) The board advisory tasks in small firms and the event of crises, Journal of Management and Governance, 11, 5-22.

Molokwu, V.B., Barreria, J. and Urban, B. (2013) Entrepreneurial orientation and corporate governance structures at the firm level in the South African oil and gas industry, South African Journal of Human Resource Management, 11(1), 1-15.

Nash, J.M. (1988) Boards of privately held companies: Their responsibilities and structure, Family Business Review, 1(3), 263-269.

Nelson, T. (2003) The persistence of founder influence: Management, ownership, and performance effects at initial public offering, Strategic Management Journal, 24(8), 707-724.

Nelson, T. and Levesque, L.L. (2007) The status of women in corporate governance in highgrowth, high-potential firms, Entrepreneurship Theory and Practice, 31(2), 209-232.

Randoi, T. and Goel, S. (2003) Ownership structure, founder leadership, and performance in Norwegian SMEs: Implications for financing entrepreneurial opportunities, Journal of Business Venturing, 18(5), 619-637.

Ranft, A.L. and O'Neill, H.M. (2001) Board composition and high-flying founders: Hints of trouble to come?, Academy of Management Executive, 15(1), 126-138.

Ritchie, J. and Richardson, S. (2000) Smaller business governance: Exploring accountability and enterprise from the margins, Management Accounting Research, 11(4), 451-474.

Rosa, P. and Scott, M. (1999) The prevalence of multiple owners and directors in the SME sector: Implications for our understanding of start-up and growth, Entrepreneurship and Regional Development, 11(1), 21-37.

Rosenstein, J. (1988) The board and strategy: Venture capital and high technology, Journal of Business Venturing, 3(2), 159-170.

Rosenstein, J., Bruno, A.V., Bygrave, W.D. and Taylor, N.T. (1993) The CEO, venture capitalists, and the board, Journal of Business Venturing, 8, 99-113.

Sapienza, H., Korsgaard, M.A., Goutlet, P.K. and Hoogendam, J.P. (2000) Effects of agency risks and procedural justice on board processes in venture capital-backed firms, Entrepreneurship and Regional Development, 12(4), 331-351.

Sapienza, H.J., Manigart, S. and Vermeir, W. (1996) Venture capitalist governance and value added in four countries, Journal of Business Venturing, 11(6), 439-469.

Scholes, L.M., Wright, M., Westhead, P., Burrows, A. and Bruining, H. (2007) Information sharing, price negotiation and management buy-outs of private family-owned firms, Small Business Economics, 29(3), 329-349.

Steier, L.P. and Miller, D. (2010) Pre- and post-succession governance philosophies in entrepreneurial family firms, Journal of Family Business Strategy, 1(3), 145-154.

Uhlaner, L., Floren, R.H. and Geerlings, J.R. (2007a) Owner commitment and relational governance in the privately held firm: An empirical study, Small Business Economics, 29(3), 275-293.

Uhlaner, L., Wright, M. and Huse, M. (2007b) Private firms and corporate governance: An integrated economic and management perspective, Small Business Economics, 29(3), 225-241.

Vandenbroucke, E., Knockaert, M. and Ucbasaran, D. (2014) Outside board human capital and early stage high-tech firm performance, Entrepreneurship Theory and Practice, 40(4), 759-779.

Van den Heuvel, J., Van Gils, A. and Voordeckers, W. (2006) Board roles in small and medium-sized family businesses: Performance and importance, Corporate Governance, 14(5), 467-485.

Van Gils, A. (2005) Management and governance in Dutch SMEs, European Management Journal, 23(5), 583-589.

Voordeckers, W., Van Gils, A., Gabrielsson, J., Politis, D. and Huse, M. (2014) Board structures and board behaviour: A cross-country comparison of privately held SMEs in Belgium, the Netherlands and Norway, International Journal of Business Governance and Ethics, 9(2), 197-219.

Watson, R. (1991) Modelling directors' remuneration decisions in small and closely-held companies, Journal of Business Finance and Accounting, 18(1), 85-98. 


\section{Handbook of research on corporate governance and entrepreneurship}

Watson, R. (1994) An empirical analysis of financial and non-financial managers' remuneration in small and medium-sized UK enterprises, Accounting and Business Research, 24(94), 176-188.

Westhead, P. (1999) Factors associated with the employment of non-executive directors by unquoted companies, Journal of Management and Governance, 3, 81-111.

Whisler, T.L. (1988) The role of the board in the threshold firm, Family Business Review, 1, 309-321.

Wijbenga, F.H., Postma, T.J.B.M. and Stratling, R. (2007) The influence if the venture capitalist's governance activities on the entrepreneurial firm's control systems and performance, Entrepreneurship Theory and Practice, 31(2), 257-277.

Williams, D.R., Duncan, W.J. and Ginter, P.M. (2006) Structuring deals and governance after the IPO: Entrepreneurs and venture capitalists in high tech start-ups, Business Horizons, 49(4), 303-311.

Wirtz, P. (2011) The cognitive dimension of corporate governance in fast growing firms, European Management Journal, 29(6), 431-447.

Zahra, S.A. (1996) Governance, ownership and corporate entrepreneurship: The moderating effect of industry technological opportunities, Academy of Management Journal, 39(6), 1713-1735.

Zahra, S.A. (2014) Public and corporate governance and young global entrepreneurial firms, Corporate Governance: An International Review, 22(2), 77-83.

Zahra, S. and Filatotchev, I. (2004) Governance of the entrepreneurial threshold firm: A knowledge-based perspective, Journal of Management Studies, 41(5), 885-897.

Zahra, S.A., Filatotchev, I. and Wright, M. (2009) How do threshold firms sustain corporate entrepreneurship? The role of boards and absorptive capacity, Journal of Business Venturing, 24(3), 248-260.

Zahra, S., Neubaum, D.C. and Huse, M. (2000) Entrepreneurship in medium-size companies: Exploring the effects of ownership and governance systems, Journal of Management, 26(5), 947-976.

Zahra, S.A. Neubaum, D.O. and Naldi, L. (2007) The effects of ownership and governance on SME's international knowledge-based resources, Small Business Economics, 29(3), 309-327.

Zhang, J.J., Baden-Fuller, C. and Pool, J. (2011) Resolving tensions between monitoring, resourcing and strategizing: Structures and processes in high technology venture boards, Long Range Planning, 44(2), 95-117. 


\section{APPENDIX 1.2}

Table 1A.1 Number of articles per academic journal

\begin{tabular}{|c|c|}
\hline & No. \\
\hline Abacus & 1 \\
\hline Academy of Accounting and Financial Studies Journal & 1 \\
\hline Academy of Management Executive & 1 \\
\hline Academy of Management Journal & 2 \\
\hline Academy of Management Review & 2 \\
\hline Accounting and Business Research & 1 \\
\hline Accounting Forum & 1 \\
\hline American Business Law Journal & 1 \\
\hline American Journal of Small Business & 1 \\
\hline Amfiteatru Economic & 1 \\
\hline British Journal of Management & 1 \\
\hline Business Horizons & 1 \\
\hline Corporate Governance: An International Review & 5 \\
\hline Corporate Governance: The International Journal of Business in Society & 1 \\
\hline $\begin{array}{l}\text { Corporate Governance: The International Journal of Effective Board } \\
\text { Performance }\end{array}$ & 1 \\
\hline Enterprise and Innovation Management Studies & 1 \\
\hline Entrepreneurship and Regional Development & 8 \\
\hline Entrepreneurship Theory and Practice & 14 \\
\hline Environment and Planning C: Government and Policy & 1 \\
\hline European Management Journal & 2 \\
\hline Family Business Review & 2 \\
\hline ICFAI Journal of Corporate Governance & 1 \\
\hline International Entrepreneurship and Management Journal & 1 \\
\hline International Journal of Business Governance and Ethics & 3 \\
\hline International Journal of Economics and Finance & 1 \\
\hline International Journal of Entrepreneurial Behaviour and Research & 1 \\
\hline International Journal of Entrepreneurship and Small Business & 1 \\
\hline International Journal of Globalisation and Small Business & 1 \\
\hline International Journal of Innovation and Technology Management & 1 \\
\hline International Research Journal of Finance and Economics & 1 \\
\hline International Small Business Journal & 1 \\
\hline International Studies of Management and Organization & 1 \\
\hline Journal of Business Finance and Accounting & 1 \\
\hline Journal of Business Research & 1 \\
\hline Journal of Business Venturing & 9 \\
\hline Journal of Disclosure and Governance & 1 \\
\hline Journal of Family Business Strategy & 2 \\
\hline Journal of High Technology Management Research & 1 \\
\hline Journal of International Entrepreneurship & 1 \\
\hline
\end{tabular}


26 Handbook of research on corporate governance and entrepreneurship

Table 1A.1 (continued)

\begin{tabular}{lr}
\hline & No. \\
\hline Journal of Management & 4 \\
Journal of Management and Governance & 4 \\
Journal of Management Studies & 2 \\
Journal of Small Business and Enterprise Development & 4 \\
Journal of Small Business Management & 2 \\
Journal of Socio-Economics & 1 \\
Journal of Technology Transfer & 1 \\
Long Range Planning & 3 \\
Management Accounting Research & 1 \\
Management Research Review & 1 \\
Management Science & 1 \\
Managerial Issues & 1 \\
Manchester School & 1 \\
Quarterly Journal of Austrian Economics & 1 \\
Research in Economics and Business Central and Eastern Europe & 1 \\
Small Business Economics & 11 \\
South African Journal of Human Resource Management & 1 \\
Strategic Management Journal & 1 \\
Technovation & 1 \\
Venture Capital: An International Journal of Entrepreneurial Finance & 2 \\
& 122 \\
\hline
\end{tabular}

